\title{
A KÖRFORGÁSOS GAZDASÁG ÉS AZ IPARI SZIMBIÓZIS MEGOLDÁSOK, MINT A FENNTARTHATÓ ERŐFORRÁSGAZDÁLKODÁS ESZKÖZEI
}

\author{
Horváth Ágnes \\ intézetigazgató, egyetemi docens, Miskolci Egyetem, Gazdaságtudományi Kar, Gazdálkodástani Intézet \\ 3515 Miskolc-Egyetemváros, e-mail: vgthagi@uni-miskolc.hu \\ Bereczk Ádám \\ egyetemi tanársegéd, Miskolci Egyetem, Gazdaságtudományi Kar, Gazdálkodástani Intézet \\ 3515 Miskolc-Egyetemváros, e-mail: bereczkadam@gmail.com
}

\begin{abstract}
Absztrakt
A fenntartható eröforrás gazdálkodás és a környezeti fenntarthatóság a modernkori vállalati eröforrás gazdálkodás kulcsfontosságú területe. A vállalkozások jelentös része épit stratégiájába ambiciózus erőforrás-optimalizálási célokat, összhangban a vállalati hatékonyság fokozásának és a természeti környezet megörzésének igényével. Cikkünk fókuszában annak bemutatása áll, hogy az iparágak szimbiózisával jelentös gazdasági és környezeti hasznok érhetök el, ugyanakkor mikro-, mezo- és makroszinten is számos akadály azonositható. A problémák jelentös részének enyhitésében az ún. facilitátoroknak lehet kiemelt szerepe. Ezen támogató szerepet betöltö szervezetek nagy segitséget jelenthetnek a szimbiózisok kialakitásában és menedzselésében a kapcsolódási lehetőségek feltárásán, az információs platformok kiépitésén és hatékony menedzselésén keresztül.
\end{abstract}

Kulcsszavak: ipari szimbiózis, körforgásos gazdaság, elektronikai ipar, fenntartható eröforrásgazdálkodás

\begin{abstract}
The concepts of sustainable resource management and environmental sustainability have become key topics in corporate management recently. Companies tend to build ambitious resource-optimization goals in their strategies, pursuing efficiency and acting towards the preservation of the natural environment at the same time. The focus of our article is to demonstrate that significant economic and environmental benefits can be achieved through the symbiosis of industries, while also a number of barriers can be identified at the micro, meso, and macro levels. In alleviating a significant part of the problems, the so-called facilitators can play a key role. These supportive organizations can be of great help in shaping and managing symbioses through exploring possible opportunities for cooperation, building information platforms, and managing them effectively.
\end{abstract}

Keywords: industrial symbiosis, circular economy, electronics industry, sustainable resource management 


\section{Bevezetés}

Az elmúlt évtizedben az iparági értékláncok mentén egyre hangsúlyosabban jelent meg egyik oldalon az erőforrásszükösség, másik oldalon a nagy mennyiségü hulladék kezelésének problémája. A globális nyersanyagtermelésben Ázsia (Kína), Észak-Amerika, Latin-Amerika, Óceánia növekedése jellemzö, az EU részaránya folyamatosan csökken. (European Commission 2018a) Mind a globális nyersanyagtermelést, mind az EU ellátási mixét tekintve magas a földrajzi koncentráció, az EU nyersanyag-importfüggősége meglehetősen magas. Ezzel párhuzamosan a jelenlegi termelési és fogyasztási minták eredményeként szembe kell néznünk a jelentős mennyiségü ipari és háztartási hulladék keletkezésének problémájával, mely rendkívüli környezeti károkat okoz. A fenntartható erőforrásgazdálkodás és a környezeti fenntarthatóság elveinek való megfelelés új megoldásokat, üzleti modelleket, új szemléletet kíván mind a vállalati szektortól, mind a fogyasztóktól. Ez az újfajta megközelítés egyre inkább a körforgásos gazdaság koncepciójában ölt testet, ami egyszerre jelenthet megoldást az erőforrás szükösség és a hulladék kezelés problémájára.

\section{A körforgásos gazdaság és az ipari szimbiózis megoldások, mint az erőforrás szűkösség és a hulladékproblémák egyidejü kezelésének eszközei}

A körforgásos gazdaság célja, hogy a termelési folyamat során kevesebb energiát és anyagot használjanak fel, valamint az anyagok mind nagyobb arányú visszaforgatása, újrahasznosítása révén minél kevesebb anyag vesszen el és kerüljön a hulladéklerakóba. A körforgásos elvek előnyei mikroszinten is realizálhatók, többek között a gyártás során keletkező melléktermékek és hulladékok hasznosításának és értékesítésének gazdasági hasznai szerint. A körforgás megvalósulásának egy fontos tényezője az iparágak összekapcsolódása, azaz az ipari szimbiózisban rejlö lehetőségek felismerése és kiaknázása. Az 1. ábra a körforgásos gazdaság koncepcióját mutatja be, az ipari szimbiózis hálózatok tipikus elemeinek és kapcsolatainak hangsúlyozásával, illetve a főbb befolyásoló tényezők megjelölésével.

$\mathrm{Az}$ 1. ábra egy értéklánc általános megközelítéséből indul ki, ahol a nyersanyag termelő és nyersanyag feldolgozó ágazatok után az „A” szektor végfogyasztásra szánt terméket állít elő a végfogyasztók számára. Bizonyos termékek esetében a termék újrahasználat formájában új gazdára talál, majd hulladék formájában a hulladék kezelö szektorba, vagy a hulladéklerakóba kerül. Az értéklánc elején szemléltettük az erőforrás szükösség, az értéklánc végén pedig a hulladék keletkezés problémáját.

Az ábrán sötét nyilak jelzik az anyagáramlás alapvető irányát a nyersanyag kitermelő szektortól a hulladék lerakók irányába, a jelenleg uralkodó lineáris üzleti modell értelmében. Az ábrán szemléltetjük a körforgásos gazdaság lehetséges megjelenését. A körforgást megtestesítő áramlási irányokat világos nyilak jelzik. Az ipari szimbiózis szempontjából legjelentősebb érintetteket világos háttérrel emeltük ki. Az anyagok újrahasznosítása elképzelhető adott szektoron belül (akár vállalaton/létesítményen belül) és különböző iparágak együttmüködése révén egyaránt. Kiemeltük az ábrán a hulladékszektor szerepét is a körforgás megvalósításának elősegítésében, mivel a hulladékok begyüjtése, kezelése, ártalmatlanítása, esetleges feldolgozása révén hozzájárul ahhoz, hogy a hulladékokból értékesíthető másodlagos nyersanyagok keletkezzenek. Végső esetben a hulladékok energetikai hasznosítása is csökkenti a hulladéklerakókba szállított anyagok mennyiségét. A hulladék szektor funkcióinak bővítése, szerepének kiterjesztése tehát szükséges feltétele az anyagok körforgása biztosításának és a hálózatok értékteremtésének (Aid et al. 2017). 


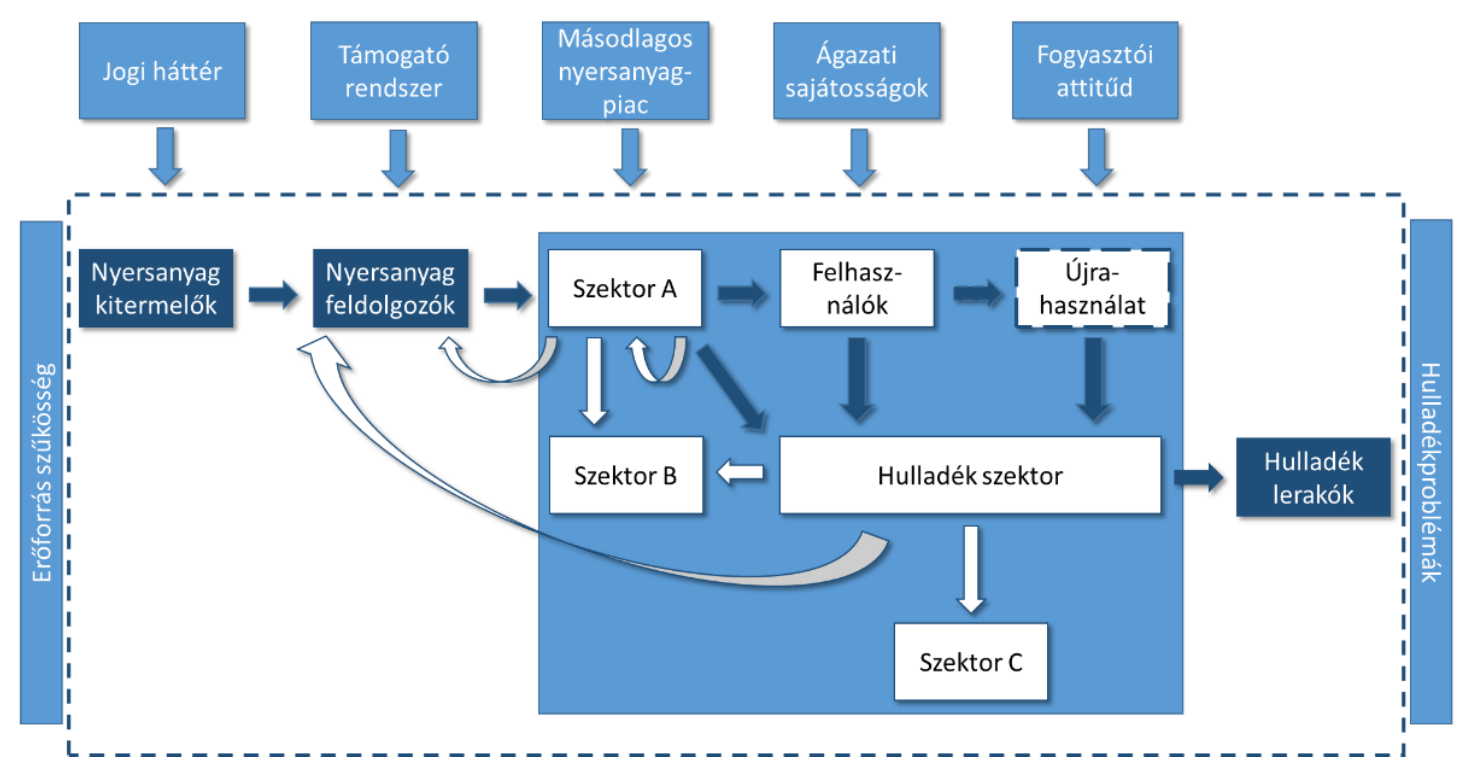

1. ábra: A körforgásos szemlélet és az ipari szimbiózis lehetőségek megjelenése egy értékláncban Forrás: saját szerkesztés, in Horváth - Bereczk (2019)

A körforgásos gazdaság elméletben megfogalmazott koncepciójának a gyakorlati megvalósítása lényegesen bonyolultabb. A sikeréhez nagyban hozzájárul a megfelelö jogszabályi háttér, illetve támogatói rendszer megléte. Elsődlegesen azonban az ágazati sajátosságok, a keletkező melléktermékek és hulladékok típusa, az újrahasznosítás lehetőségei és gazdasági életképessége, a másodlagos nyersanyag piac helyzete, a vállalatok közötti távolság, valamint a vállalati és fogyasztói attitüdök befolyásolják a körforgásos szemlélet megvalósulásának sikerét. Fontos megjegyezni, hogy a fejlesztési irányok egy jelentős meghatározója a földrajzi távolság és területi koncentrációk. Ez egybecseng Bartha és Gubik 2019-es tanulmányával, ahol a szerzők a legintenzívebb gazdasági kapcsolatok feltételeként a térbeli agglomerációkat nevezik meg. (Bartha - Gubik 2019)

Mint láthattuk, a körforgásos gazdaság kiépülésében kiemelkedő szerepe van az iparágak közötti együttmüködési lehetőségeknek. Az ipari szimbiózisban rejlő szinergiák kihasználásának lényege, hogy egy vállalat melléktermékét/hulladékát egy másik vállalat inputként használja fel termelési folyamataihoz. Ez ideális esetben hozzájárul a vásárló fél erőforrásigényének fenntartható kielégítéséhez, és egyben hozzásegíti az értékesítő vállalkozásokat, hogy megfelelő értéken ismertessék el folyamataik melléktermékeit (és/vagy hulladékait). Ipari szimbiózis esetén tehát (leginkább) különböző ágazatokban müködő vállalkozások olyan együttmüködéséről van szó, melyek erőforrás beszerzési igényeik és hulladékkezelésük összekapcsolásával kölcsönös előnyöket keresnek a környezeti fenntarthatóság szempontjainak figyelembevétele mellett. (Európai Bizottság 2018/b) Jóllehet az együttmüködések magukban foglalhatnak jelentős tudás- és technológiatranszfereket is, ebben a tanulmányban az Európai Bizottság megközelítését alkalmazva ipari szimbiózis hálózatoknak azon hálózatokat tekintjük, melyek középpontjában a fizikai anyagáramlások, illetve energia transzfer állnak. Másik oldalról fontos hangsúlyozni, hogy az ipari szimbiózis rendszerek az egyszerü hulladékmenedzsment témakörtől lényegesen szélesebb összefüggéseket ölelnek fel, ahol az egyik fö cél az anyagoknak minél tovább tartó áramoltatása az ipari rendszerekben, mielött hulladékként a természetet terhelnék. 


\section{A probléma érzékeltetése az elektronikai ipar példáján keresztül}

Az erőforrás szükösség, és ezzel párhuzamosan a keletkező hulladékok kezelésének problémája az elektronikai iparban is hangsúlyosan jelenik meg. Az elektronikai termékek gyártása jelentős nyersanyagigénnyel és a másik oldalon jelentős hulladéktermeléssel jár. Ez egyrészt a gyártási folyamat energia- és anyagigényességéből, másrészt a legyártott termékek jellemzőiből, illetve azok felhasználási módozataiból következik. Az elektronikai iparba a nemzetközi szakmai gyakorlatnak megfelelően az alábbi alágakat soroltuk be:

- C26: Számítógép, elektronikai, optikai termék gyártása

- C27: Villamos berendezés gyártása

Az iparág által felhasznált nyersanyagok többsége az EU 2017. évi besorolása alapján kritikusnak tekinthető (2. ábra). Az EU által vizsgált 76 nyersanyag közül 42 nyersanyag valamilyen formában felhasználásra kerül az elektronikai iparban. A kritikus anyagok 2017. évi értékelési módszertana alapján két tényező mentén történik az anyagok kritikusság szerinti besorolása. A gazdasági jelentőség (küszöbérték: 2,8) és az ellátási kockázat (küszöbérték: 1) alapján látható, hogy az elektronikai iparban felhasznált nyersanyagok jelentős része (76,2 százaléka) a kritikus nyersanyagok körébe tartozik (jobb felső negyed), veszélyeztetve a fenntartható erőforrásgazdálkodást. Fontosnak tartjuk kiemelni Kína jelentőségét, 26 anyag esetében ő tekinthető a domináns termelőnek.

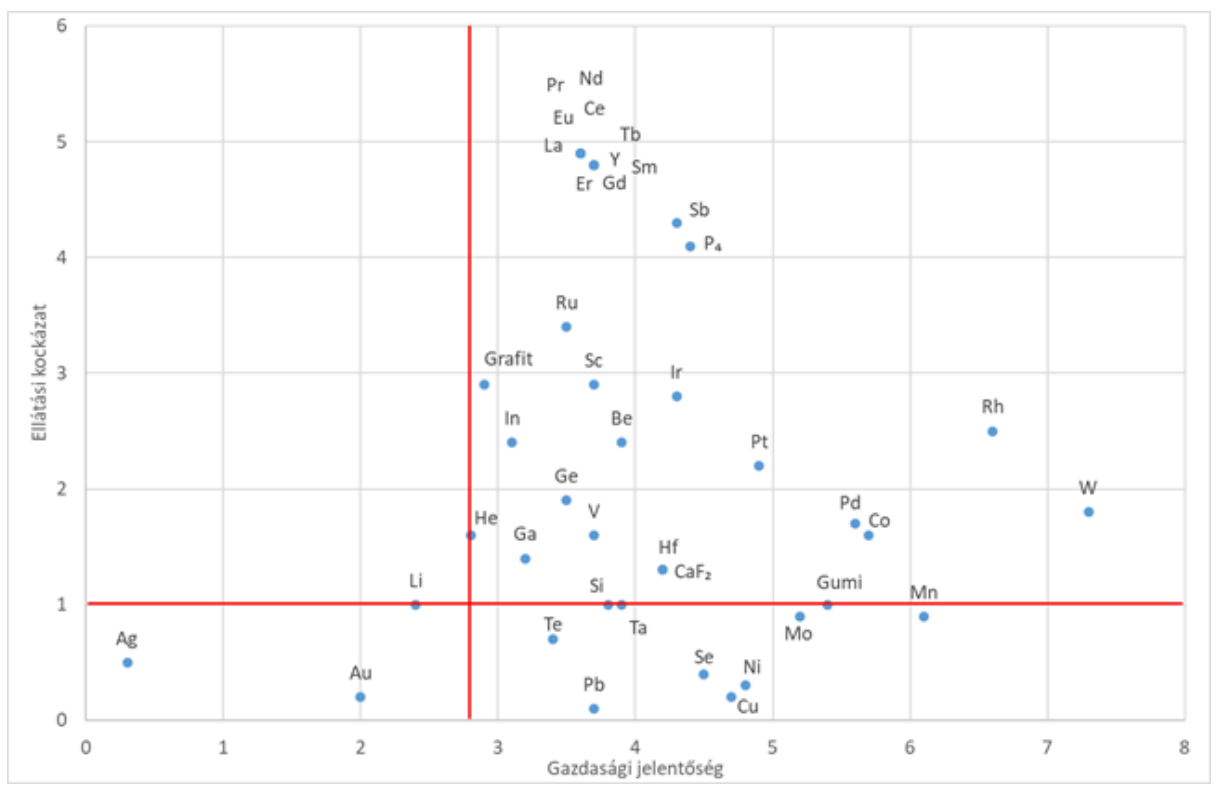

2. ábra. Az elektronikai ipar által felhasznált nyersanyagok kritikusság szerinti besorolása Forrás: European Commission 2017a,b,c adatai alapján saját szerkesztés

A 3. ábra az életciklus végéhez kapcsolódó újrahasznosítási arányt (bal oldal) (ez az adott nyersanyag régi hulladékból történő újrahasznosításának az uniós kereslethez viszonyított aránya) és az EU importfüggőségét (jobb oldal) mutatja az egyes anyagok esetében. Látható, hogy az anyagok jelentős hányadánál igen alacsonynak mondható az élettartam végi újrahasznosítás aránya az uniós kereslethez viszonyítva, és az anyagok döntő többségénél 80 százalék feletti az EU importfüggősége. 

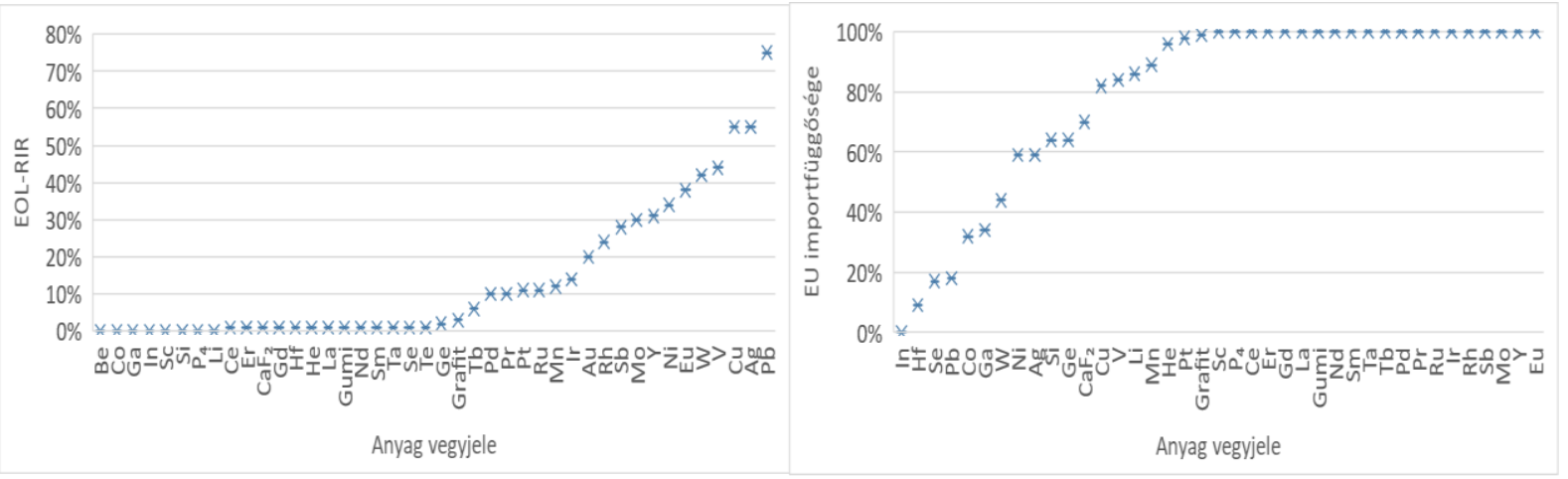

3. ábra: Az életciklus végéhez kapcsolódó újrahasznosítási arány (EOL-RIR) (bal oldal) és az EU importfüggősége (jobb oldal) az elektronikai iparban felhasznált nyersanyagok esetében Forrás: European Commission 2017a,b,c adatai alapján saját szerkesztés

A hulladék képződés terén az elektronikai hulladék (e-hulladék) nagy mennyiségü keletkezését kell kiemelnünk az iparággal kapcsolatban.

A magyarországi háztartások elektronikai hulladék termelése 2008-ról 2017-re több mint megháromszorozódott (13.000 tonnáról 47.000 tonnára nőtt). Eközben az e-hulladékok újrahasznosítási rátája a 2011-es 25\%-ról 2017-re 51\%-ra nőtt. (OECD és EUROSTAT adatbázisok, 2020. januári állapot szerint) Az elektronikai ipar termékeiből (illetve a gyártásuk során) keletkező e-hulladékok jelentős gazdasági értéket képviselnek és komoly környezeti hatással bírnak az anyagok összetétele és a gyártás tömegszerüsége okán. Amellett, hogy egyre inkább igény mutatkozik a keletkező hulladékok adatainak összegyüjtésére, sajnos ez idáig az e-hulladékok nagyobb része esetében nincs dokumentálva az elhasználódott, életciklusuk végére ért termékek sorsa. Egy jelentős részük informális kereskedelmi csatornákon keresztül folytatja útját, illetve hulladék exporton keresztül a harmadik világ országaiba kerül, ahol egy részét újrafeldolgozzák, másik része kérdéses eljárású folyamatok során visszakerül a környezetbe. Globálisan az anyagok egyharmadát használják újra, mely komoly gazdasági veszteséget jelent és nehezen felmérhetö környezeti terhelést okoz. (Marconi et al. 2018; Duan et al. 2016)

Említést érdemel a közlekedésben az elektromos jármüvek irányába történő elmozdulás hatása is. Az elektromos autók és ehhez kapcsolódóan a Li-ion akkumulátorok gyártása során egyre több nagyértékü, kritikus nyersanyagot használnak fel. A kritikus nyersanyagok elégtelen mennyisége és földrajzilag egyenlötlen eloszlása fennakadásokat okozhat az ellátási láncban. Ezt a kockázatot csökkentheti egy megfelelő élettartam-végi infrastruktúra megteremtése, mely biztosítja az élettartamuk végén az elektromos járművek gyüjtését, válogatását, szétszerelését és az értékes anyagok elkülönítését. (Mathura et al. 2019) Kiemelt szerepe van a lítium-ion akkumulátorok újrahasznosítási lehetőségeinek, figyelembe véve, hogy az ajánlások szerint az elektromos jármüvek akkumulátorait ki kell cserélni, ha teljesítőképességük az eredeti állapot 80 -ára csökken. Ha azonban ezeket a használt akkumulátorokat fel lehetne használni kevésbé igényes alkalmazásra (például a fotovoltaikus (PV) technológiával elő́llított megújuló energia tárolására a napelemek esetén), akkor jelentős primer nyersanyag lenne megtakarítható. (Mathur et al. 2019). A napjainkat és a jövőt meghatározó energiaátmenet küszöbén a megújuló energiák fokozódó térhódításának lehetünk tanúi. A megújuló energiaforrások közül a napenergia hasznosítása a villamos energiatermelésben drasztikusan megemelkedett. Jelenleg még nem okoz ugyan jelentős problémát az elhasználódott napelemek kezelése az élettartamuk végén, mivel jelentős részük még használatban van. Azonban a közeljövőben nagymértékben meg fog emelkedni az 
élettartamuk végét elért napelemek száma. Mathur et al. 2020 felhívja a figyelmet a hatékony EoLkezelési (élettartam végi) módszerek kidolgozásának és megvalósításának szükségességére annak érdekében, hogy ne kerüljön nagy mennyiségü veszélyes hulladék hulladéklerakókba. Emellett a PVhulladék értékes anyagok potenciális forrásaként is felfogható, és ezáltal jelentős primer nyersanyag és energiafelhasználás váltható ki, hozzájárulva ezzel a fenntartható erőforrásgazdálkodáshoz és a környezeti terhelés csökkenéséhez. (Mathur et al. 2020)

Látható, hogy a körforgásos szemlélet megjelenése alapvető jelentőségü az elektronikai ipar esetében. A teljes életciklus szemléletben a körforgásos elvek már a termék tervezésekor megjelennek, beleértve a gyártáshoz szükséges nyersanyagok kitermelésével kapcsolatos környezeti hatások elemzését is. De ide tartozik a termékek tartósságának növelése, a moduláris felépítés, a javíthatóság növelése, mellyel az élettartam meghosszabbítható. A termelöi és vásárlói attitüdök vizsgálata nem része jelen cikknek, azonban fontos kiemelni azt a tényt, hogy az elektronikai ipar számos terméke esetében nagy kihívást (és egyben dilemmát) jelent a termékek tartósságának növelése, amiatt, hogy az IT és kommunikációs technológia fejlődésével a fogyasztók mindig a legújabb technológiákat igénylik. A körforgásos elvek teljesíthetősége emiatt leginkább a melléktermékek és a hulladékok értékesítési lehetőségében, illetve az élettartam végi kezelési módszerek, infrastruktúrák kiépítésében jelenik meg az ágazatban. Ennek sikeres megvalósítása érdekében azonban szükség van az iparági együttmüködési lehetőségek feltárására, valamint az ipari szimbiózisban rejlő lehetőségek felismerésére és kiaknázására.

\section{Az ipari szimbiózisok kialakulását támogató és akadályozó tényezők}

A továbbiakban áttekintjük a szimbiózis hálózatok hajtóerőit és korlátait. A hajtóerők ismertetését a Domenech et al., 2019 tanulmányában szereplő felsorolás szerint ismertetjük. A szerzők a szimbiózis hálózatok facilitátorai körében végzett kérdőives felmérésük, szakértőkkel végzett mélyinterjúik és fókuszcsoportos vizsgálataik alapján nyerték eredményeiket. A hajtóerők sorrendje azok jelentőségének megfelelően kerül bemutatásra. (1. táblázat)

1. táblázat Az ipari szimbiózis hálózatok vállalati hajtóerői

\begin{tabular}{|l|l|}
\hline 1. & Erőforrásmegtakaritáson keresztül elérhetö költségcsökkentések \\
\hline 2. & A vállalati hulladéktermelés csökkentése \\
\hline 3. & Pótlólagos bevételszerzési lehetöségek \\
\hline 4. & Jövedelmezöség növelése \\
\hline 5. & Vállalatközi együttmüködések erösítése \\
\hline 6. & A vállalati környezetvédelmi célok teljesülésének elösegítése \\
\hline 7. & Fenntarthatóbb üzleti modell \\
\hline 8. & A hulladéklerakók használatának kiváltása \\
\hline 9. & Innováció megjelenése a vállalatban \\
\hline 10. & Új ügyfelek szerzése \\
\hline 11. & Az inputok minőségének és biztonságának növekedése \\
\hline 12. & A vállalati társadalmi felelösségvállalási célok megvalósísa \\
\hline 13. & Munkahelyteremtés \\
\hline
\end{tabular}

Forrás: Domenech et al. 2019

Megállapítható, hogy a szimbiózisok kialakulásának jelentős motivációját adják a vállalatok gazdasági érdekei, az öt legjelentősebb vállalati hajtóerő közül három közvetlenül pénzben mérhető 
előnyök szerzésére vonatkozott. Jelentős hajtóeröt jelent továbbá a hulladéktermelés csökkentésének lehetősége, illetve fontos értéknek tartják a vállalatok a szimbiózisok révén megerősödő vállalatközi együttmüködéseket is.

Az akadályok számbavételéhez három forrásra támaszkodtunk: Aid és szerzőtársainak 2017-es, Domenech és szerzőtársainak 2019-es tanulmányaira, valamint az Európai Bizottság 2018-os (European Commission 2018/b) jelentésére. A feldolgozott munkákban szereplő tényezőket azok jellege alapján újra csoportokba rendeztük. A tényezők elemzésekor arra a következtetésre jutottunk, hogy az együttmüködés akadályai meglehetősen eltérő jellegüek. Tartalmaznak olyan elemeket, melyek a vállalkozások számára adottságként jelennek meg (illetve megváltoztatásuk bonyolult és/vagy költséges), mint a szabályozási jellemzők, vagy a másodlagos nyersanyagok piaci viszonyai. A technológiai adottságok jelentette korlátok szintén nem tekinthetők rugalmas feltételeknek, tekintve az elérhető technológiák adta lehetőségeket, a változtatások tőkeigényét és a vállalatok ilyen irányú döntéseinek motivációit. Azonosítható azonban a tényezőknek egy másik nagy csoportja, ahol az elörelépés feltételei leginkább tudás- és információmenedzsment illetve szervezési összefüggésekben keresendők. A csoportok közötti fent említett lényegi különbségeket megjelenítendő a tényezőket két különálló táblázatba rendeztük, „Intelligencia és együttmüködés típusú akadályok” (2. táblázat), illetve „Egyéb akadályozó tényezők” (3. táblázat) címekkel.

2. táblázat „Intelligencia és együttmüködés” típusú akadályok

\begin{tabular}{|c|c|c|}
\hline \multirow{6}{*}{$\begin{array}{l}\text { Információ- } \\
\text { ellátottság } \\
\text { / } \\
\text { vállalati } \\
\text { intelligencia }\end{array}$} & \multicolumn{2}{|c|}{ Információhiány az együttmüködési lehetőségekröl } \\
\hline & \multicolumn{2}{|c|}{ Információhiány az elérhető hasznokról } \\
\hline & \multicolumn{2}{|c|}{ Információhiány a lehetséges együttmüködési módozatokról } \\
\hline & \multicolumn{2}{|c|}{ Információhiány a kapcsolódó piacokról } \\
\hline & \multicolumn{2}{|c|}{$\begin{array}{l}\text { A vállalat hulladékkezeléséhez kapcsolódó költségek elégtelen nyomon } \\
\text { követése }\end{array}$} \\
\hline & \multicolumn{2}{|c|}{$\begin{array}{l}\text { A vállalati információs rendszerek és a fenntarthatósági információigények } \\
\text { összhangjának hiánya }\end{array}$} \\
\hline \multirow{10}{*}{ Együttmüködés } & \multirow{3}{*}{$\begin{array}{l}\text { Tranzakciós } \\
\text { költségek }\end{array}$} & A partnerkeresés költségei \\
\hline & & $\begin{array}{l}\text { A szimbiózis hálózatokban való részvétel költségei (pl. tagdíjak, } \\
\text { szolgáltatási díjak) }\end{array}$ \\
\hline & & $\begin{array}{l}\text { A partnerségek kialakításának és fenntartásának járulékos } \\
\text { költségei (tárgyalási költségek, időráfordítás) }\end{array}$ \\
\hline & \multirow{7}{*}{$\begin{array}{l}\text { Kapcsolat- } \\
\text { építési } \\
\text { akadályok }\end{array}$} & Függőség kialakulásától való félelem \\
\hline & & A változástól való félelem \\
\hline & & Eltérő vállalati és kommunikációs kultúrák okozta nehézségek \\
\hline & & Bizalomhiány \\
\hline & & $\begin{array}{l}\text { Az együttmüködésbe bekapcsolódó további szereplök } \\
\text { megjelenésétől való tartózkodás (pl. kormányzati szervezetek) }\end{array}$ \\
\hline & & A kockázat és felelősség megosztás problematikája \\
\hline & & Előnyök megosztásának nehézségei \\
\hline
\end{tabular}

Forrás: Aid et al. 2017, Domenech et al. 2019 és Európai Bizottság 2018

Megállapítható, hogy a szimbiózisok megvalósulásának vállalati és vállalatközi szinten is számos olyan akadálya van, mely alapvetően információhiányra, vagy az információk elszigeteltségére vezethető vissza. Így többek között a vállalkozások nem rendelkeznek elegendő információkkal az 
együttműködési lehetőségekröl és módozatokról, a kapcsolódó piacok létezéséröl és müködéséről, ezen felül nincsenek tisztában az együttmüködés révén elérhető hasznokkal sem. Eközben fontos volna az is, hogy a vállalkozások erőforrásgazdálkodási információs rendszerei összhangba kerüljenek a körforgásos gazdaság követelményeivel. A valóságban azonban a vállalkozások sokszor aktuális hulladékmenedzsment megoldásaik tényleges költségeit sem mérik fel megfelelően.

Az, hogy az együttmüködések akadályai között magas arányban található az informáltsággal, motivációkkal kapcsolatos „szoft” tényező, fontos eredmény. Ezen hiányosságok kezelésére más területeken sokszor külső szereplőket alkalmaznak. Egy hatékony támogató infrastruktúra a tranzakciós költségek csökkentésében, de a technológiai, piaci és szabályozási feltételek javításában is szerepet vállalhat, így javítva az együttmüködések várható megtérülésén, ezen keresztül is növelve a vállalkozások szimbiózis jellegü kapcsolatépítési hajlandóságát.

\begin{tabular}{|c|c|}
\hline & akaaalyozo tenyezok \\
\hline \multirow{6}{*}{$\begin{array}{l}\text { Technológia } \\
\text { és logisztika }\end{array}$} & Tároló kapacitások hiánya \\
\hline & $\begin{array}{l}\text { A vállalati folyamatok és termelési eljárások szükséges módosításaiból eredő } \\
\text { költségek }\end{array}$ \\
\hline & Magas szállítási költségek \\
\hline & Üzemek közötti távolságok \\
\hline & Technológiai szakértelem hiánya \\
\hline & Magas szintủ logisztikai képességek hiánya \\
\hline \multirow{6}{*}{ Szabályozás } & Bonyolult adminisztratív követelmények \\
\hline & Rugalmatlan szabályozások, elsősorban a hulladékkezelés területén \\
\hline & Szigorú engedélyezési elöírások \\
\hline & A támogató jellegü szabályozások hiánya \\
\hline & Az elsődleges kitermelő ágazatok állami támogatása \\
\hline & A szabályozások, elöírások bonyolultsága \\
\hline \multirow{3}{*}{ Piacok } & Instabil piacok \\
\hline & Bonyolult és változékony piaci viszonyok \\
\hline & $\begin{array}{l}\text { A költség-haszon kimenetek és jövedelmezőségi hatások elörejelzésének } \\
\text { bizonytalanságai }\end{array}$ \\
\hline \multirow{3}{*}{ Megtérülés } & Nem jövedelmező együttmüködési lehetőségek \\
\hline & $\begin{array}{l}\text { Gazdaságilag kifizetődőbb alternatívák (pl. szemétégetés, szeméttelepen való } \\
\text { elhelyezés) }\end{array}$ \\
\hline & Hosszú megtérülési idők és az ehhez illeszkedő finanszírozás hiánya \\
\hline
\end{tabular}

Forrás: Aid et al. 2017, Domenech et al. 2019 és Európai Bizottság, 2018

\section{Következtetések, javaslatok}

A vállalkozások szimbiózison alapuló összekapcsolásával jelentős gazdasági és környezeti hasznok érhetők el. A szakirodalom alapján jól körbeírhatók a folyamatokra pozitívan ható tényezők, és fejlett elméleti módszertani keretek állnak rendelkezésre a kapcsolatok fejlesztésére, ugyanakkor mikro-, mezo- és makroszinten is számos akadály azonosítható. Jelen tanulmányban azt hangsúlyoztuk, hogy az akadályok egy jelentős része arra vezethető vissza, hogy a vállalkozások nem rendelkeznek elegendő információval az ipari szimbiózis jellegü együttműködési lehetőségekről, együttmüködési módozatokról, a kapcsolódó piacok létezéséről és müködéséről és szintén nincsenek tisztában az 
együttműködés révén elérhető hasznokkal sem. Ezzel párhuzamosan az együttműködési lehetőségek felkutatását és a partnerkapcsolatok menedzselését a vállalkozások túl költségesnek gondolják, és az előzőkkel is összefüggésben gyakran elutasító hozzáállást tanúsítanak.

A problémák jelentős részének enyhítésében az ún. facilitátoroknak lehet kiemelt szerepe. Ezen támogató szerepet betöltő szervezetek nagy segítséget jelenthetnek a szimbiózisok kialakításában és menedzselésében a kapcsolódási lehetőségek feltárásán, az információs platformok kiépítésén és hatékony menedzselésén keresztül, mellyel a tranzakciós költségek is lényegesen csökkenthetők. Ezen túlmenően szerepet vállalhatnak a technológiai akadályok leküzdésében vagy a szabályozások befolyásolásában is. Amennyiben ilyen jellegü funkciójukat a vállalatok is felismerik, számítani lehet azok együttmüködési attitüdjének javulására (mely szintén jelentős akadályt jelent). Pozitív példaként említhető egy, az angol International Synergies szervezet által indított korábbi kezdeményezés, a National Industrial Symbiosis Programme (NISP), amelyet a világ első nemzeti ipari szimbiózis programjaként tartanak számon. A hálózat célja az volt, hogy azonosítsa a kölcsönösen jövedelmező tranzakciókat a partnerek számára, amelyek az ipari hálózat egyik szereplöjénél keletkező felesleges erőforrások, anyagok partnernél történő feldolgozását, újrahasznosítását, újrahasználatát jelentik. (Brányi 2012) A NISP résztvevői között voltak mikrovállalkozások, kis- és középvállalkozások és multinacionális / nagyvállalatok minden ipari szektorból. A program megvalósítása során 2005-2013 között jelentős eredményeket értek el, így például nagymértékben csökkent a hulladéklerakóba került ipari hulladékok mennyisége, csökkent a $\mathrm{CO} 2$ kibocsátás, jelentős megtakarítást realizáltak a primer nyersanyag felhasználásban, az ipari vízfelhasználásban, emellett a vállalatok számára anyagi előnyök is kimutathatóak voltak azáltal, hogy felvevőpiacot találtak az ipari hulladékaik számára, és csökkentek az ártalmatlanítási, tárolási, szállítási és beszerzési költségeik. Társadalmi hatásként pedig kiemelendő a program jelentős munkahelyteremtő hatása. (www.international-synergies.com) A programhoz 2010ben Magyarország is csatlakozott, az Iparfejlesztési Közalapítvány kezdeményezésében. Modelljét eddig világszerte 20 országban alkalmazták. Az azóta eltelt idôben számos hasonló program is indult (lásd pl. FISSAC projekt (Fostering Industrial Symbiosis for a Sustainable Resource Intensive Industry across the extended Construction Value Chain), mely az építö- és a bontóipar ágazati szereplöit tömöríti az értéklánc minden szintjén). A már megvalósult programok gyakorlati tapasztalatai alapján bizonyítható az ipari szimbiózison alapuló együttműködések pozitív gazdasági és környezeti hatása. Az említett potenciálok ellenére a szimbiózisok támogatására szakosodott, közvetítői szektor Európai Uniós szinten is fejlődésének kezdeti szakaszában jár. (Európai Bizottság 2018)

\section{Köszönetnyilvánítás}

A cikkben ismertetett kutató munka az EFOP-3.6.1-16-2016-00011 jelü „Fiatalodó és Megújuló Egyetem - Innovatív Tudásváros - a Miskolci Egyetem intelligens szakosodást szolgáló intézményi fejlesztése" projekt részeként - a Széchenyi 2020 keretében - az Európai Unió támogatásával, az Európai Szociális Alap társfinanszírozásával valósul meg.

\section{Irodalom}

[1] Aid, G., Eklund, M., Anderberg, S., Baas, L. (2017): Expanding roles for the Swedish waste management sector in inter-organizational resource management. Resources, $\begin{array}{llll}\text { Conservation } & \text { And } & \text { 85-97. }\end{array}$ https://doi.org/10.1016/j.resconrec.2017.04.007 
[2] Bartha, Z., Sáfrányné Gubik, A. (2019): Technológiai lehetőségek - társadalmi leképeződések. Észak-magyarországi Stratégiai Füzetek XVI. évf. 2019/1. 95-105.

[3] Brányi, Z. (2012): Másoljuk le a természetet - A Nemzeti Ipari Szimbiózis Program Magyarországon. Ipari Ökológia pp. 135-140. (2012) 1. évfolyam 1. szám

[4] Cronauge, U. (1992): Kommunale Unternehmen. Berlin: Erich Schmidt Verlag

[5] Domenech, T., Bleischwitz, R., Doranova, A., Panayotopoulos, D., Roman, L. (2019): Mapping industrial symbiosis development in europe - typologies of networks, characteristics, performance and contribution to the circular economy. Resources, Conservation and Recycling, 141. 76-98. https://doi.org/10.1016/j.resconrec.2018.09.016

[6] Duan, H., Hu, J., Yuan, W., Wang, Y., Yu, D., Song, Q., Li, J. (2016): Characterizing the environmental implications of the recycling of non-metallic fractions from waste printed circuit boards. Journal of Cleaner Production, 137. 546-554. https://doi.org/10.1016/j.jclepro.2016.07.131

[7] European Commission (2017/a): Study on the Review of the List of Critical Raw Materials. Criticality Assessments. Brüsszel: Európai Bizottság https://op.europa.eu/en/publication-detail/-/publication/08fdab5f-9766-11e7-b92d01aa75ed71a1

[8] European Commission (2017/b): Study on the Review of the list of Critical Raw Materials. Critical Raw Materials Factsheets. Brüsszel: Európai Bizottság https://op.europa.eu/en/publication-detail/-/publication/7345e3e8-98fc-11e7-b92d01aa75ed71a1/language-en

[9] European Commission (2017/c): Study on the Review of the list of Critical Raw Materials. Non-critical Raw Materials Factsheets. Brüsszel: Európai Bizottság https://op.europa.eu/en/publication-detail/-/publication/6f1e28a7-98fb-11e7-b92d01aa75ed71a1/language-en

[10] European Commission (2018/a): EIP on Raw Materials, Raw Materials Scoreboard 2018, European Union, 2018

[11] European Commission (2018/b): Cooperation Fostering Industrial Symbiosis: Market Potential, Good Practice And Policy Actions. Brüsszel: Európai Bizottság.

[12] Horváth, Á., Bereczk, Á. (2019): Az ipari szimbiózis szerepe a fenntartható erőforrásgazdálkodásban. Észak-Magyarországi Stratégiai Füzetek, XVI. évfolyam 3. szám, pp. 99-109., 11 p.

[13] Marconi, M., Gregori, F., Germani, M., Papetti, A., Favi, C. (2018): An approach to favor industrial symbiosis: the case of waste electrical and electronic equipment. Procedia Manufacturing, 21. 502-509. https://doi.org/10.1016/j.promfg.2018.02.150

[14] Mathur, N. - Deng, S. - Singh, S. - Yih, Y. -Sutherland, J.W.: Evaluating the environmental benefits of implementing Industrial Symbiosis to used electric vehicle batteries. Procedia CIRP, Volume 80, 2019, Pages 661-666 https://doi.org/10.1016/j.procir.2019.01.074 
[15] Mathur, N., Singh, S., Sutherland, J.W. (2020): Promoting a circular economy in the solar photovoltaic industry using life cycle symbiosis. Resources, Conservation and Recycling Volume 155, April 2020, 104649 https://doi.org/10.1016/j.resconrec.2019.104649

[16] OECD adatbázisok: https://stats.oecd.org/Index.aspx?DataSetCode=AEA

[17] Eurostat adatbázisok: https://ec.europa.eu/eurostat/data/database

[18] International Synergies: www.international-synergies.com

[19] Fissac: http://fissacproject.eu/hu/ 